\title{
Tidal and seasonal effects on transport of pink shrimp postlarvae
}

\author{
Maria M. Criales ${ }^{1, *}$, John Wang ${ }^{2}$, Joan A. Browder ${ }^{3}$, Michael B. Robblee ${ }^{4}$ \\ ${ }^{1}$ Marine Biology \& Fisheries, Rosenstiel School of Marine and Atmospheric Science (RSMAS), and \\ ${ }^{2}$ Applied Marine Physics, Rosenstiel School of Marine and Atmospheric Science (AMP), \\ University of Miami, 4600 Rickenbacker Causeway, Miami, Florida 33149, USA \\ ${ }^{3}$ NOAA Fisheries, Southeast Fisheries Science Center, 75 Virginia Beach Drive, Miami, Florida 33149, USA \\ ${ }^{4}$ United States Geological Survey, Center for Water and Restoration Studies, 9100 NW 36th Street, Miami, Florida 33178, USA
}

\begin{abstract}
Transport simulations were conducted to investigate a large seasonal peak in postlarvae of the pink shrimp Farfantepenaeus duorarum that occurs every summer on the northwestern border of Florida Bay. Daily vertical migration, a known behavior in pink shrimp postlarvae, was assumed in all scenarios investigated. A Lagrangian trajectory model was developed using a current field derived from a 3 yr ADCP (Acoustic Doppler Current Profiler) time series. To fit the estimated planktonic development time of pink shrimp, the model simulated larvae traveling at night over a $30 \mathrm{~d}$ period. We investigated 2 types of effects: (1) the effect of mismatch periodicity between tidal constituents and daily migration, and (2) the effect of seasonal changes in night length. The maximum eastward displacement with the semidiurnal lunar tidal constituent $\left(\mathrm{M}_{2}\right)$ was $4 \mathrm{~km}$, with periods of enhanced transport in both summer and winter. In contrast, eastward displacement with the semidiurnal solar tidal constituent $\left(\mathrm{S}_{2}\right)$ and the lunisolar diurnal $\mathrm{K}_{1}$ was $65 \mathrm{~km}$ and the period of maximum distance occurred in summer every year. Because the periods of $\mathrm{S}_{2}$ and $\mathrm{K}_{1}$ are so close to the $24 \mathrm{~h}$ vertical migration period, and the eastward current (flood) of these constituents matches the diel cycle over extended intervals, they can induce strong horizontal transport during summer. Thus, diel vertical migration can interact with the $\mathrm{S}_{2}$ and the $\mathrm{K}_{1}$ tidal constituents and with the annual cycle of night length to produce a distinct annual cycle that may enhance transport of pink shrimp and other coastal species during summer in shallow areas of the Gulf of Mexico.
\end{abstract}

KEY WORDS: Mismatch periodicity · Tidal transport - Daily migration · Pink shrimp Resale or republication not permitted without written consent of the publisher

\section{INTRODUCTION}

The life cycle of the pink shrimp Farfantepenaeus duorarum is qualitatively understood: the adults and spawning events occur in areas E-NE of the Dry Tortugas along the SW Florida shelf, while juveniles occupy nursery grounds in Florida Bay (see Fig. 1). Postlarvae may enter Florida Bay through: (1) the tidal channels of the Lower and Middle Florida Keys (Munro et al. 1968, Criales \& McGowan 1994) or (2) the NW boundary of Florida Bay (Rehrer et al. 1967, Jones et al. 1970, Criales \& Lee 1995). Transport through the channels in the Middle Florida Keys has been the most widely recognized pathway because of the favorable onshore Ekman transport and coastal countercurrent flow generated by cyclonic eddies (Lee \& Williams 1999, Yeung et al. 2001, Criales et al. 2003). However, recent results from an ongoing field study comparing the 2 hypothesized migration routes showed that the greater postlarval influx ( $>70 \%$ ) occurred at the NW border of the Bay, where there was a strong seasonal pattern with a high peak of postlarvae from July through September each year (Criales et al. in press). Onshore surface currents and winds on the SW Florida shelf are weak. Winds have a seasonal pattern and a primarily alongshore (N-S) direction (Lee et al. 2001). 
Densities of pink shrimp postlarvae in 3 yr of data were correlated with alongshore winds and sea-surface temperature (Criales et al. in press). However, these correlations did not explain the long cross-shelf (West to East) distance (about $150 \mathrm{~km}$ ) that postlarvae need to traverse to reach the nursery grounds of Florida Bay.

On many parts of the shallow continental shelves, currents are dominated not by a steady flow but by oscillatory motions of the tides. Organisms inhabiting these coastal waters can control the direction of transport by using the recurring tidal currents (Shanks 1995). Because tidal currents are not unidirectional, the animals will encounter both favorable and unfavorable flow directions. However, organisms may behaviorally select currents by vertical migration (Dittel \& Epifanio 1990), or by timing spawning to the lunar cycle (Christy 1982, 1986) or to the diel cycle (Queiroga et al. 1994). Invertebrates and fishes maximize horizontal movement in estuarine and coastal areas or, conversely, display retention in certain areas, by regulating their position in the water column in relation to the speed and direction of the tidal current, a mechanism known as selective tidal stream transport (STST) (see review in Forward \& Tankersley 2001). A notable aspect of STST within any one species is the reversal in direction of migration at different life stages (Dall et al. 1990, Forward \& Tankersley 2001), which has been observed for pink shrimp Farfantepenaeus duorarum in south Florida. Pink shrimp postlarvae use flood-tide transport to move up the estuary by positioning themselves from just above the bottom to about $0.5 \mathrm{~m}$ from the surface (Tabb et al. 1962, Hughes 1969a,b, Criales et al. 2000), and juveniles use ebb-tide transport to move out of the estuary by locating themselves in the upper layer (from the surface down to about $1.5 \mathrm{~m}$ depth) (Idyll et al. 1963, Hughes 1969b). However, the depth of occupancy of the water column varies among locations and species of penaeid shrimps (Duronslet et al. 1972). The behavioral response of pink shrimp postlarvae to the tidal currents was clearly confirmed at the border of Florida Bay with the SW Florida shelf, where about $90 \%$ of postlarvae entering the Bay were collected during the dark-flood period (Criales et al. in press). Simulations of transport using this particular STST behavior for the whole larval development period indicated that planktonic stages (larvae/postlarvae) consistently travel between 100 and $200 \mathrm{~km}$ in $30 \mathrm{~d}$, and hypothetically $85 \%$ of postlarvae reach the nursery grounds.

In order to enhance tidal transport when day/night vertical migration is the principal behavior, 2 conditions must be present: (1) the period of the tidal component must closely match the diel period so that a particular (favorable) component phase can be maintained for many days; (2) the favorable phase (eastward current) must coincide with the dark (night) hours. By means of a simple model using sinusoidal migration and linear shear, Hill (1991a,b, 1995) quantified the influence of vertical migration, and showed that substantial net horizontal transport results when the period of the larval vertical migration and the tidal period are exact multiples or 'phase-locked'. The semidiurnal lunar tidal constituent $\left(\mathrm{M}_{2}\right)$, the most pronounced tidal constituent on the SW Florida shelf, has a periodicity of $12.42 \mathrm{~h}$; however, the much weaker semidiurnal solar tidal constituent $\left(\mathrm{S}_{2}\right)$ has a $12 \mathrm{~h}$ periodicity that matches exactly the $24 \mathrm{~h}$ diel migration period. Hill (1991a,b, 1995) did not consider annual seasonal changes in day length and the spring-neap tides, which may affect transport of a nocturnally or diurnally active animal. Smith \& Stoner (1993), using a 2D model, included day length and the effect of turbulent diffusion in vertical migration to examine the effect of diel and tidal vertical migration schemes on the long-term net transport of larvae in 2 tidal channels dominated by semidiurnal (Exuma Cays, Bahamas) and diurnal (Aransas Pass, Texas Gulf coast) tides. They concluded that diurnal migrations under both tidal conditions (diurnal and semidiurnal) resulted in annual cycles in net transport, but a relatively small steady transport. A more recent study by Power (1997) investigated the interaction between predicted tidal current flow and the day-night cycle for 11 locations within the United States and found that seasonal periodicities differ among locations.

The present study investigated the effect of the mismatch periodicity and seasonal changes in night length on transport of pink shrimp larvae/postlarvae migrating over the SW Florida shelf and displaying day/night behavior.

\section{MATERIALS AND METHODS}

Time series of currents were obtained from ADCPs moored at 2 stations on the inner SW shelf of the Gulf of Mexico, about $30 \mathrm{~km}$ from Cape Sable (A and B: Fig. 1). This array monitored coastal currents as part of the 'Florida Bay Circulation and Exchange Study' (Lee et al. 2001). The ADCP moorings were located at depths of $6.4 \mathrm{~m}$ (Mooring A) and $11.6 \mathrm{~m}$ (Mooring B) and recorded data every $30 \mathrm{~min}$ for a $3 \mathrm{yr}$ period $(\mathrm{A}=$ 21 September 1997 to 15 October 2000; B = 22 September 1997 to 17 October 2000). The 2 ADCP moorings were about $30 \mathrm{~km}$ apart. Lee et al. (2001) reported insignificant vertical differences between currents for cross-shelf transport in the shallow SW Florida shelf. Current vectors were resolved into cross-shelf, $u$ (positive toward east) and alongshore, $V$ (positive toward north) constituents. An harmonic analysis was conducted on a continuous $183 \mathrm{~d}$ segment of the ADCP 


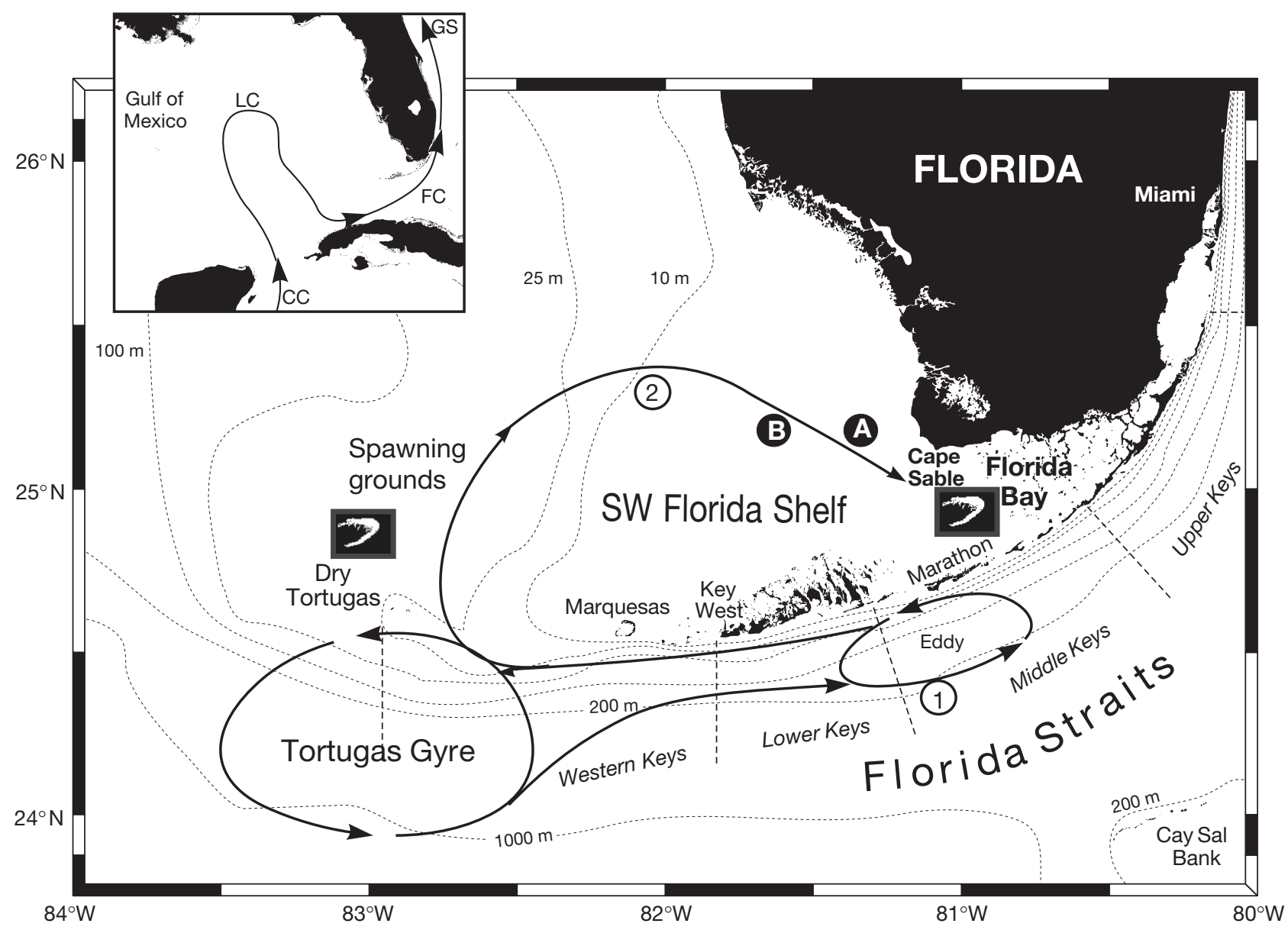

Fig. 1. Study area, showing hypothesized recruitment pathways (1 and 2) for planktonic stages of pink shrimp Farfantepenaeus duorarum (adapted from Lee \& Williams 1999). Spawning grounds at Dry Tortugas, nursery grounds at Florida Bay and ADCP stations A and B on inner SW Florida shelf of the Gulf of Mexico are also shown. Inset shows main oceanographic features: CC, Caribbean Current; LC, Loop Current; FC, Florida Current; GS, Gulf Stream

time-series raw data to define tidal constituents and current magnitude (see Table 1). Surface currents ca. $1 \mathrm{~m}$ below the water surface (mean $=6$ and $9.5 \mathrm{~m}$ above the bottom for Moorings $\mathrm{A}$ and $\mathrm{B}$, respectively), and bottom currents ca. $1 \mathrm{~m}$ above the bottom were used for this analysis. Surface tidal ellipses were constructed for the $\mathrm{M}_{2}$ constituent using a clockwise rotation.

A simple lagrangian trajectory model of transport was developed using 3 yr ADCP time series to explore transport mechanisms across the shelf. The model used the observed currents at ADCP Moorings A and B to calculate trajectories. Because only 2 ADCPs (A and B) provided the current data for this large region, a simple 2-dimensional (horizontal) simulation model was used in which the currents observed at A and B were used independently, as if the current field were spatially homogenous. No attempts were made to extrapolate to a spatially varying current field because of the difficulty of extrapolating vertical current profiles from one depth and bottom relief to other conditions across the shelf.
A fundamental behavioral assumption of the model was that larvae travel only at night. Near-surface currents were selected for this transport analysis since vertical differences in currents were not substantial for cross-shelf transport (Lee et al. 2001) (see Table 1). In the first simulation (Model 1), larvae were deployed every $2 \mathrm{~d}$ at night for a $3 \mathrm{yr}$ period, and the maximum advection distance of the larvae over $30 \mathrm{~d}$ was calculated; $30 \mathrm{~d}$ is the estimated development period of pink shrimp from hatching to presettlement postlarvae (Dobkin 1961, Ewald 1965). Alternative transport simulations were developed using the different constituents of harmonic analysis. A simulation (Model 2) was developed using the lunar semidiurnal tidal $M_{2}$, which was the dominant tidal constituent (see Table 1); 1 larvae was deployed every hour for a 1 yr period and the maximum eastward distance traveled by the larvae at night over $30 \mathrm{~d}$ was calculated. The amplitude of $M_{2}\left(0.32 \mathrm{~m} \mathrm{~s}^{-1}\right)$ and the length of the night (which varied from $13.95 \mathrm{~h}$ in winter to $8.95 \mathrm{~h}$ in summer) were used in the simulation with the $\mathrm{M}_{2}$. Another simulation 
(Model 3) was developed adding the tidal constituents, solar semidiurnal $\mathrm{S}_{2}$ (period of $12 \mathrm{~h}$ ) and lunisolar diurnal $\mathrm{K}_{1}$ (period of $23.93 \mathrm{~h}$ ), using the amplitudes from the harmonic analysis and the same variations in length of the night from the previous simulation. Each simulation was run for the 3 yr period of ADCP data.

\section{RESULTS}

Simulations of transport with the instantaneous current for the 2 ADCP data sets for travel only at night (Model 1) indicated that larvae can reach a maximum distance of $70 \mathrm{~km}$ in $30 \mathrm{~d}$ (Fig. 2). The $15 \mathrm{~d}$ fluctuation in the simulated distance traveled along the $3 \mathrm{yr}$ trajectory is due to the variable current magnitudes during spring-neap tides. Predicted periods of enhanced transport were not always correlated with seasons. Results from ADCP A indicated that maximum distance traveled during the first year occurred in spring-summer (May to September 1998); however, during the second and part of the third years, the maximum distance was in fall-winter (October 1999 to February 2000). Results from ADCP B showed that the maximum distances traveled were in summer (July to September), except in the third year.

Results of the harmonic analysis showed that semidiurnal tidal constituents $\left(\mathrm{M}_{2}, \mathrm{~S}_{2}\right.$, and $\left.\mathrm{N}_{2}\right)$ are dominant on the SW Florida shelf (Table 1). The E-W component of the semidiurnal tidal constituent $\mathrm{M}_{2}$ was $0.32 \mathrm{~m} \mathrm{~s}^{-1}$ and explained about $95 \%$ of the total cross-shelf current variance for both data sets. The other semidiurnal and diurnal constituents have amplitudes $\leq 0.1 \mathrm{~m} \mathrm{~s}^{-1}$. The E-W amplitude of the $\mathrm{M}_{2}$ constituent is several magnitudes higher than that reported for the Florida Keys region $\left(\mathrm{M}_{2}=0.064 \mathrm{~m} \mathrm{~s}^{-1}\right.$, Shay et al. 1998; $0.18 \mathrm{~m} \mathrm{~s}^{-1}$, Smith 1994) but of similar magnitude to that reported for Western Florida Bay $\left(\mathrm{M}_{2}=0.382 \mathrm{~m} \mathrm{~s}^{-1}\right.$, Smith 2000). The near-surface amplitudes were slightly stronger than those near the bottom, and the phases of both layers were similar, indicating very little change in direction of the current with depth (Table 1). The major axes of the surface tidal ellipses from both sites were E-W oriented with E-W speeds several times greater than $\mathrm{N}-\mathrm{S}$ speeds; this difference was more pronounced at Mooring B (farther offshore) than Mooring A (Fig. 3).

Displacement on the semidiurnal tidal constituent $\mathrm{M}_{2}$ during 1 yr (using Model 2) indicated that the periods of maximum transport were spring, summer, and winter (Fig. 4). Maximum displacement during the
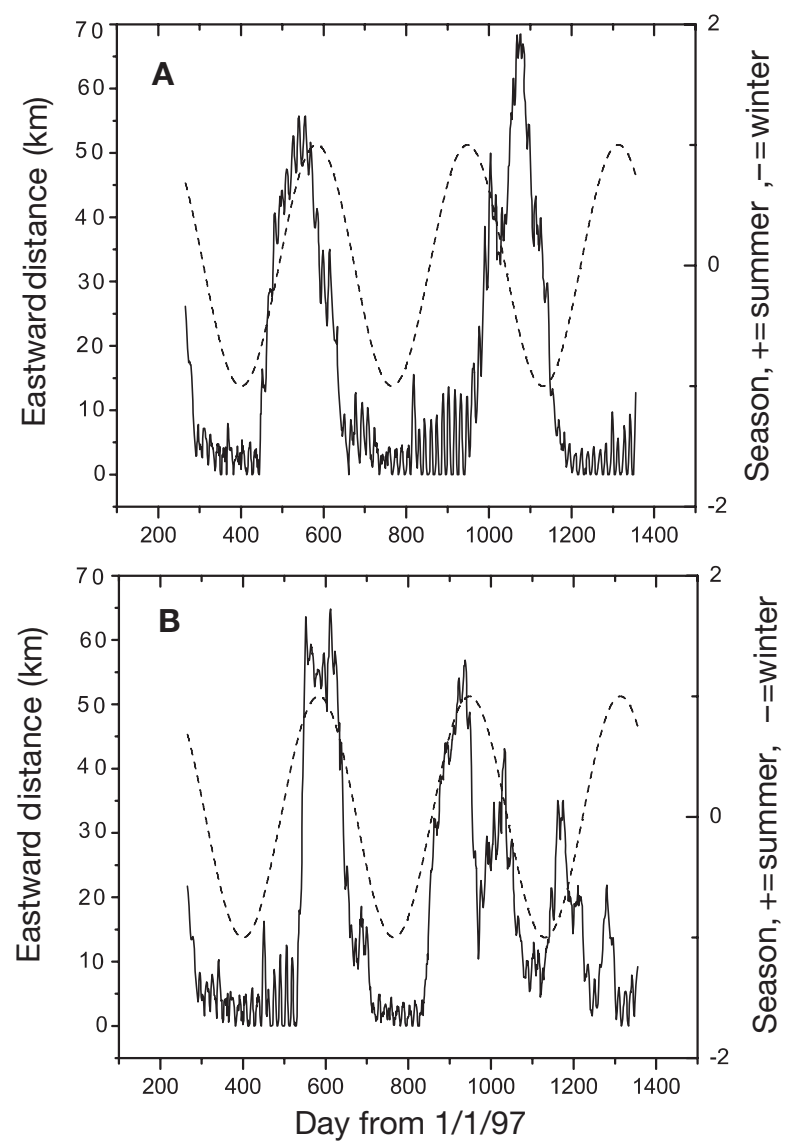

Fig. 2. Output of simulation of transport (Model 1) developed from surface current observations for 3 yr (September 1997 to October 2000), whereby maximum eastward distance traveled by larvae at night was calculated every $30 \mathrm{~d}$. The superimposed dashed curves represent seasons, with summer positive and winter negative right $y$-axis. (A) ADCP Mooring $\mathrm{A}_{\text {; }}$ and (B) ADCP Mooring B

Table 1. Amplitude and relative phase of main diurnal and semidiurnal tidal components derived from harmonic analysis conducted on surface and bottom currents ( 6 and $1 \mathrm{~m}$ above bottom, respectively) from ADCP (Acoustic Doppler Current Profiler). Mooring A was located on SW Florida shelf; time series was from September 1997 to October 2000. Explained variance of E-W component was $95 \%$ and of $\mathrm{N}-\mathrm{S}$ component $50 \% . \mathrm{M}_{2}$ : semidiurnal lunar; $\mathrm{S}_{2}$ : semidiurnal solar; $\mathrm{N}_{2}$ : semidiurnal layer lunar elliptic; $\mathrm{K}_{1}$ : diurnal lunisolar; $\mathrm{M}_{1}$ : diurnal smaller lunar elliptic; $\mathrm{O}_{1}$ : diurnal principal lunar; $\mathrm{K}_{2}$ : semidiurnal lunisolar

\begin{tabular}{|llcccccccc|}
\hline \multirow{2}{*}{ Parameter } & \multirow{2}{*}{ Depth } & \multicolumn{7}{c|}{ Tidal component } \\
\cline { 3 - 9 } & & $\mathrm{M}_{2}$ & $\mathrm{~S}_{2}$ & $\mathrm{~N}_{2}$ & $\mathrm{~K}_{1}$ & $\mathrm{O}_{1}$ & $\mathrm{~K}_{2}$ & $\mathrm{M}_{1}$ \\
\hline E-W component & & & & & & & \\
Phase $\left(^{\circ}\right)$ & Surface & -84.9 & 128.8 & 120.5 & -62.4 & 108.9 & -78.0 & 153.1 \\
& Bottom & -86.2 & 130.5 & 122.2 & -61.4 & 115.5 & -82 & 147.4 \\
Amplitude & Surface & 32.1 & 10.0 & 5.6 & 4.9 & 3.9 & 2.5 & 0.5 \\
$\left(\mathrm{~cm} \mathrm{~s}^{-1}\right)$ & Bottom & 26.9 & 8.7 & 4.9 & 4.4 & 3.4 & 1.9 & 0.5 \\
$\mathbf{N - S ~ c o m p o n e n t ~}$ & & & & & & & \\
Phase $\left(^{\circ}\right)$ & Surface & -162.3 & 71.9 & 49.4 & -146.3 & 11.9 & -156.4 & 134.5 \\
& Bottom & -161.8 & 72.2 & 51.1 & -146.9 & 21.9 & -157.5 & 97.5 \\
Amplitude & Surface & 6.98 & 1.74 & 1.32 & 1.49 & 0.98 & 0.99 & 0.11 \\
$\left(\mathrm{~cm} \mathrm{~s}^{-1}\right)$ & Bottom & 5.31 & 1.51 & 1.15 & 1.3 & 0.98 & 0.65 & 0.16 \\
\hline
\end{tabular}




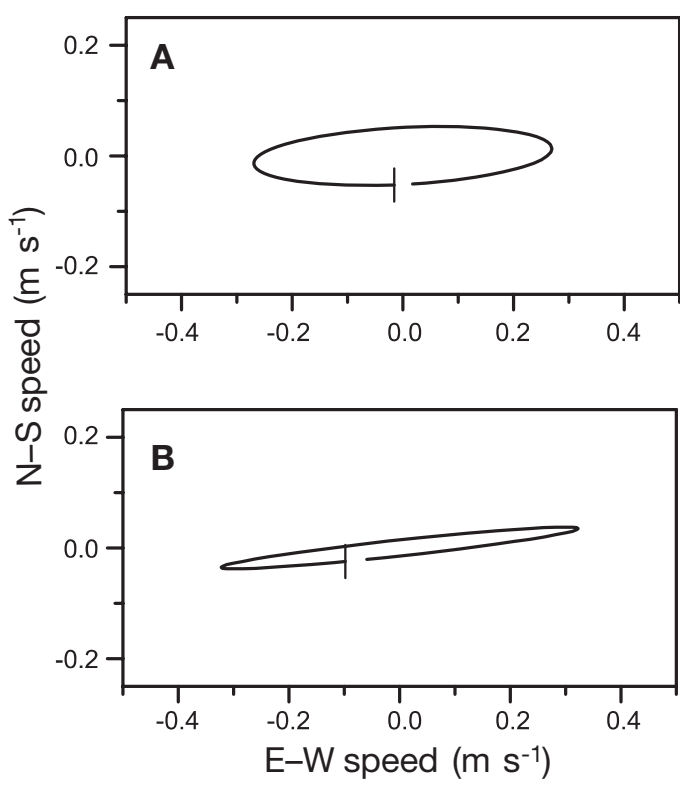

Fig. 3. Surface tidal ellipses for semidiurnal lunar tidal constituent, $\mathrm{M}_{2}$, using clockwise rotation. (A) ADCP Mooring $\mathrm{A}_{\text {; }}$ and (B) ADCP Mooring B

period of darkness in summer occurred when the lunar phase was such that particles traveled mostly eastward during the night. During winter, night length was fairly close to the semidiurnal $12.4 \mathrm{~h}$ period and much of the distance traveled in one direction was canceled when the current reversed, resulting in smaller travel distances in winter. The maximum eastward movement was independent of duration of the lunar phase as long as this was longer than $7.5 \mathrm{~d}$ (half the spring/neap cycle). Furthermore, the distance traveled with the $\mathrm{M}_{2}$ constituent was only about $4 \mathrm{~km}$. This short distance is

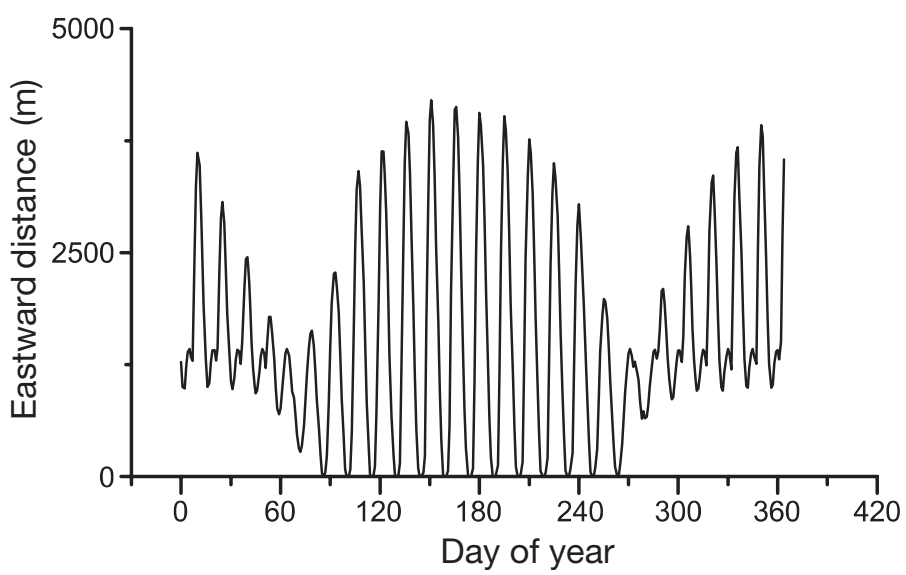

Fig. 4. Output of simulation of transport (Model 2) developed with semidiurnal tidal constituent $\mathrm{M}_{2}$ obtained from harmonic analysis. Maximum eastward distance traveled by a larva in $30 \mathrm{~d}$ was calculated throughout $1 \mathrm{yr}$ period. Model assumptions explained in 'Materials and methods' believed to be due to the mismatch between the periods of the $\mathrm{M}_{2}$ constituent and the $24 \mathrm{~h}$ day, which prevents the favorable lunar phase from persisting over many days. As a result, vertical migration in response to light and darkness with only the $\mathrm{M}_{2}$ tide is an ineffective mechanism for long-distance postlarval displacement.

The $\mathrm{S}_{2}$ tidal constituent has a period which is exactly one-half of $24 \mathrm{~h}$, and the period of the $\mathrm{K}_{1}$ tidal constituent very closely approximates $24 \mathrm{~h}$. As a resut the constituents maintain approximately the same phase with the local earth day over long periods $(1 \mathrm{mo})$ and could produce substantially larger displacements even though they have much smaller amplitudes than the dominant $\mathrm{M}_{2}$. Results of simulations with these constituents (Model 3) indicated that the period of maximum eastward distance traveled during a $30 \mathrm{~d}$ period with the semidiurnal $\mathrm{S}_{2}$ and diurnal $\mathrm{K}_{1}$ constituents was summer for each of the $3 \mathrm{yr}$ of data (Fig. 5). The eastward distance traveled with the semidiurnal $\mathrm{S}_{2}$ was about $25 \mathrm{~km}$ and with the diurnal $\mathrm{K}_{1}$ about $40 \mathrm{~km}$. The maximum eastward distance traveled when all constituents were summed together was about $70 \mathrm{~km}$, which means that other tidal constituents besides $\mathrm{S}_{2}$ and $\mathrm{K}_{1}$ contributed only $5 \mathrm{~km}$ to total displacement.

This transport is a result of a phase match, or covariance, between current and diel behavior of the shrimp larvae. When these 2 factors have different periods, the transport within a certain time interval is controlled by their relative phases, which are constantly chang-

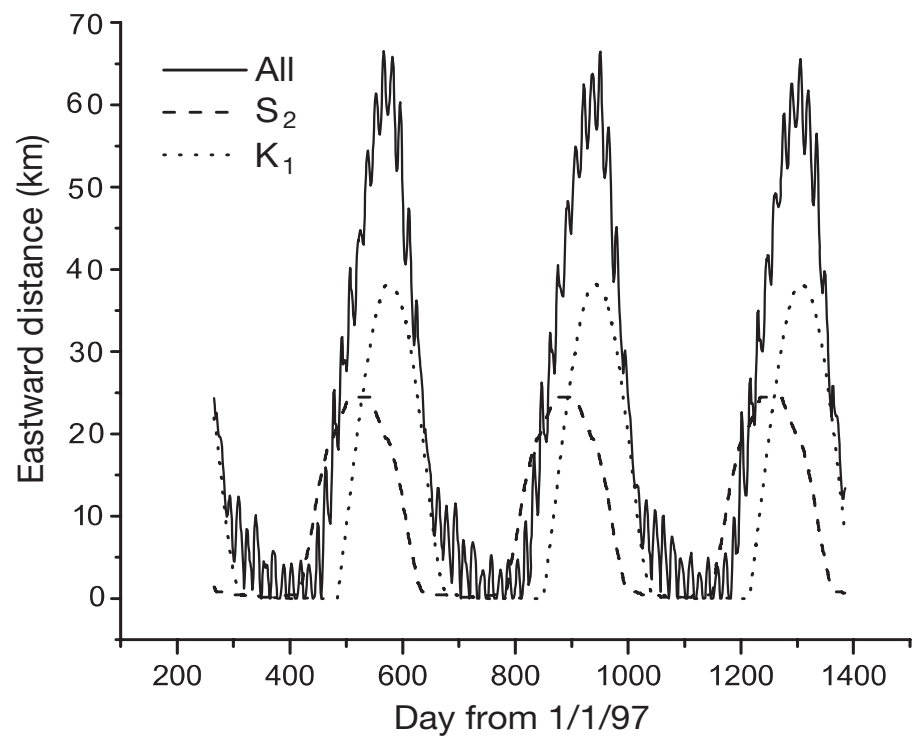

Fig. 5. Output of simulation of transport (Model 3) developed with semidiurnal solar tidal constituent $\mathrm{S}_{2}$, lunisolar diurnal constituent $\mathrm{K}_{1}$, and all tidal constituents together, obtained from harmonic analysis. Maximum eastward distance traveled by larvae in $30 \mathrm{~d}$ was calculated for 3 yr period. Model assumptions explained in 'Materials and methods' 
ing. Consequently, the covariance oscillates around zero, limiting maximum transport distance. At certain times, the 2 factors can work together and achieve positive transport, but eventually (after a time equal to $t_{1} \times$ $t_{2} / 2\left(t_{1}-t_{2}\right)$, where $t_{1}$ and $t_{2}$ are the respective periods of the 2 factors viz. current and shrimp larval behavior) the relative phases will change, so that the transport becomes negative, limiting transport in one direction.

\section{DISCUSSION}

Results of simulations indicated that pink shrimp larvae migrating vertically on a day-night cycle and traveling with the semidiurnal $\mathrm{M}_{2}$ tidal constituent alone traversed only about $4 \mathrm{~km}$. This short displacement confirmed Hill's (1991a,b) hypothesis of the effect of mismatched periodicity on net coastward transport of animals displaying diel vertical migration behavior. Diel vertical migration solely with an $\mathrm{M}_{2}$ tidal current is thus ineffective in generating net transport. In contrast, transport with the semidiurnal $\mathrm{S}_{2}$ (which has a period of exactly $12 \mathrm{~h}$ ) and with the diurnal $\mathrm{K}_{1}$ (with a period of $23.93 \mathrm{~h}$ ) allows phase-locking to persist over many days. When the eastward current (flood) of these constituents matches the diel cycle over extended intervals, which can occur only during summer, the period of shorter nights, larvae can reach distances of up to $70 \mathrm{~km}$ in $30 \mathrm{~d}$. If planktonic stages of pink shrimp are able to recognize and use the eastward current (flood), they may travel between 150 and $200 \mathrm{~km}$ in $30 \mathrm{~d}$ (Criales et al. in press). In these simulations the period of maximum distance traveled occurred every year in summer. Because of the shorter nights in summer, postlarvae may be transported farther eastward because they can be transported coastward for the entire dark-flood period. During winter, the dark period is longer and covers some hours of ebb (reverse current). A long interval during which the eastward current occurred at night was recorded in summer of each year; this correlates with the large peak of postlarvae entering Florida Bay every summer. Our simulation results suggest that diel vertical migration can interact with the $\mathrm{S}_{2}$ and $\mathrm{K}_{1}$ and the annual cycle of night length to induce effective net coastward transport of pink shrimp larvae during summer on the SW Florida shelf.

The present study has clearly demonstrated a distinct annual tidal cycle that supports the seasonal postlarval pattern of pink shrimp in NW Florida Bay. An annual tidal cycle has previously been reported to support the seasonal postlarval recruitment of the penaeid shrimp Melicertus latisulcatus in Western Australia (Penn 1975). The largest peak of postlarvae migrating into the nursery ground of Shark Bay occurs in summer during periods of a net tidal flow at night (Penn 1975). The white shrimp Litopenaeus setiferus in the northern Gulf of Mexico also has its primary spawning season and postlarval migration into the estuaries in summer (June to August) (Lindner \& Anderson 1956, Lindner \& Cook 1970). This seasonality agrees with the summer net tidal import reported for the northern Gulf of Mexico by Smith \& Stoner (1993). In contrast, for other commercial important penaeid shrimps such as the brown shrimp Farfantepenaeus aztecus in the northern Gulf of Mexico and the grooved tiger prawn Penaeus semisulcatus in the Gulf of Carpenteria, Australia, the 2 main spring and fall spawning seasons do not agree with the annual tidal cycles reported for their respective regions (Barton et al. 1993, Rothlisberg et al. 1995). Coastal penaeid shrimps and other fish and invertebrate species that use tidal currents for transport with daily vertical migration may take advantage of the annual tidal cycles to improve their chances of reaching coastal nursery habitats. However, it is clear that the amplitude of the seasonal periodicities differs among locations (Power 1997).

The maximum distance traveled by larvae with the tidal currents during day-night cycles was about $70 \mathrm{~km}$ in $30 \mathrm{~d}$, about half the distance that larvae need to travel to reach the nursery grounds. Obviously, this mechanism cannot account for the entire journey of pink shrimp planktonic stages. Densities of pink shrimp postlarvae over a $3 \mathrm{yr}$ period correlated with alongshore but not with cross-shelf winds (Criales et al. in press), and larvae need to travel about $150 \mathrm{~km}$ eastward across the shelf to reach the nursery grounds of Florida Bay. Seasonal winds and residual currents may not explain the eastward transport mechanism of larvae across the shelf, but may cause the interannual variability observed in the recruitment data. An alternative mechanism suggested in previous research is that penaeid postlarvae are able to recognize and act upon changes in the direction of the current by an endogenous circatidal activity rhythm (Hughes 1969b, 1972, Matthews et al. 1991). Simulation of this particular STST behavior indicated that larvae consistently travel between 100 and $200 \mathrm{~km}$ in $30 \mathrm{~d}$, and hypothetically $85 \%$ of larvae reached the nursery grounds (Criales et al. in press). However, early life stages (nauplii, zoeae and myses) may not undertake a STST (Rothlisberg et al. 1983, 1995) and may first depend upon simple diel migration for transport. The results of the present study indicate that simple diel migration, in interaction with $\mathrm{S}_{2}, \mathrm{~K}_{1}$, and $\mathrm{M}_{2}$, can transport earlystage shrimp up to $70 \mathrm{~km}$ in the direction of the nursery grounds. Results derived from several studies on pink shrimp in south Florida indicated that early planktonic stages migrate vertically, increasing their mobility gradually with increasing age. Zoeal and myses stages 
were found near the bottom, while postlarvae were found throughout the water column. During the day most shrimp larvae were on the bottom; at night occupancy percentages increased at the surface and in midwater, although a substantial percentage were still on the bottom (Jones et al. 1970). However a significant difference in depth of water column occupation between day and night has not been found for early planktonic stages of pink shrimp (Eldred et al. 1965, Temple \& Fisher 1965, Jones et al. 1970, Criales \& Lee 1995). The behavior of early stages near the spawning grounds needs to be explored in the context of the questions raised by the simulations. This may lead to refinement of the scenarios. In addition, scenarios need to be coupled to a complete hydrodynamic model with winds and spatial and vertical variations in currents for a better understanding of the interaction between advection, vertical migration, and environmental cues.

Acknowledgements. Our thanks to T. Lee, E. Williams, N. Smith, E. Johns, R. Smith, S. Cummings and N. Melo for collecting and providing ADCP data, to C. Hittle, T. Jackson, A. Daniels and $\mathrm{H}$. Cardenas for their assistance in the field trips collecting plankton samples and environmental data, and to the journal's referees for improving the manuscript. This research was funded by the NOAA South Florida Ecosystem Restoration Prediction and Modelling (SFERPM) program through a cooperative agreement between Southeast Fisheries Science Center, USGS and CIMAS, RSMAS, University of Miami, and the DOI Critical Ecosystems Studies Initiative of the Everglades Restoration Program.

\section{LITERATURE CITED}

Barton DR, Shaw RF, Herke WH, Blanchet RH (1993) Recruitment of postlarval and juvenile brown shrimp (Penaeus aztecus Ives) from offshore to estuarine waters of the Northwestern Gulf of Mexico. Estuar Coast Shelf Sci 36: 377-394

Christy JH (1982) Adaptive significance of semilunar cycles of larval release in fiddler crabs (genus Uca): test of an hypothesis. Biol Bull (Woods Hole) 163:251-263

Christy JH (1986) Timing of larval release by intertidal crabs on an exposed shore. Bull Mar Sci 39:176-191

Criales MM, Lee TN (1995) Larval distribution and transport of penaeoid shrimps during the presence of the Tortugas Gyre in May-June 1991. Fish Bull (Seattle) 93:471-482

Criales MM, McGowan MF (1994) Horizontal and vertical distribution of penaeidean and caridean larvae and micronektonic shrimps in the Florida Keys. Bull Mar Sci 54: 843-856

Criales MM, Bello MJ, Yeung C (2000) Diversity and recruitment of penaeoid shrimps at Bear Cut, Biscayne Bay, Florida. USA. Bull Mar Sci 67:773-788

Criales MM, Yeung C, Jones D, Jackson TL, Richards WJ (2003) Variation of oceanographic processes affecting the size of pink shrimp (Farfantepenaeus duorarum) postlarvae and their supply to Florida Bay. Estuar Coast Shelf Sci 57: $457-468$
Criales MM, Wang J, Browder JA, Robblee MB, Jackson TL, Hittle C (in press) Variability in supply and cross-shelf transport of pink shrimp postlarvae into western Florida Bay. Fish Bull (Seattle)

Dall W, Hill BJ, Rothlisberg PC, Staples DJ (1990) The biology of Penaeidae. Adv Mar Biol 27:1-489

Dittel AI, Epifanio CH (1990) Seasonal and tidal abundance of crab larvae in a tropical mangrove system, Gulf of Nicoya, Costa Rica. Mar Ecol Prog Ser 65:25-34

Dobkin S (1961) Early development stages of pink shrimp, Penaeus duorarum, from Florida waters. Fish Bull US Fish Wildl Serv Fish Bull (Seattle) 61:321-349

Duronslet M, Lyon J, Marullo F (1972) Vertical distribution of postlarval brown Penaeus aztcus, and white, P. setiferus, shrimp during immigration through a tidal pass. Trans Am Fish Soc 4:749-752

Eldred JW, Martin GT, Joyce EA (1965) Seasonal distribution of penaeid larvae and postlarvae of the Tampa Bay area, Florida. Fla Board Conserv Mar Res Lab Tech Ser 44:1-47

Ewald JJ (1965) The laboratory rearing of pink shrimp, Penaeus duorarum Burkenroad. Bull Mar Sci 15: 436-449

Forward RB, Tankersley RA (2001) Selective tidal-stream transport of marine animals. Oceanogr Mar Biol Annu Rev 39:305-353

Hill AE (1991a) A mechanism for horizontal zooplankton transport by vertical migration in tidal currents. Mar Biol 111:485-492

Hill AE (1991b) Vertical migration in tidal currents. Mar Ecol Prog Ser 75:39-54

Hill AE (1995) The kinematical principles governing horizontal transport induced by vertical migration in tidal flows. J Mar Biol Assoc UK 75:3-13

Hughes DA (1969a) Responses to salinity change as a tidal transport mechanism of pink shrimp, Penaeus duorarum Burkenroad. Biol Bull (Woods Hole) 136:45-53

Hughes DA (1969b) Evidence for the endogenous control of swimming in pink shrimp, Penaeus duorarum. Biol Bull (Woods Hole) 136:398-404

Hughes DA (1972) On the endogenous control of tideassociated displacements of pink shrimp, Penaeus duorarum Burkenroad. Biol Bull (Woods Hole) 142:271-280

Idyll CP, Iversen ES, Yokel B (1963) Movements of juvenile pink shrimp in the Everglades National Park, Florida. (Abstract) Proc Gulf Caribb Fish Inst 16:51-52

Jones AC, Dimitriou DE, Ewald JJ, Tweedy JH (1970) Distribution of early developmental stages of pink shrimp, Penaeus duorarum, in Florida water. Bull Mar Sci 20: $634-661$

Lee TN, Williams E (1999) Mean distribution and seasonal variability of coastal currents and temperature in the Florida Keys with implications for larval recruitment. Bull Mar Sci 64:35-56

Lee TN, Johns E, Wilson D, Williams E, Smith NP (2001) Transport processes linking south Florida coastal ecosystems. In: Porter J, Porter K (eds) Linkages between ecosystems in the South Florida hydroscape. CRC Press, Boca Raton, FL, p 309-342

Lindner MJ, Anderson WW (1956) Growth, migration, spawning and size distribution of shrimp Penaeus setiferus. US Fish Wildl Serv Fish Bull 106:555-645

Lindner MJ, Cook HL (1970) Synopsis of biological data on the white shrimp Penaeus setiferus. FAO Fish Rep 57: $1439-1470$

Matthews TR, Schroeder WW, Stearns DE (1991) Endogenous rhythm, light and salinity effects on postlarval brown shrimp Penaeus aztecus Ives recruitment to estuaries. J Exp Mar Biol Ecol 154:177-189 
Munro JL, Jones AC, Dimitriou DE (1968) Abundance and distribution of the larvae of the pink shrimp (Penaeus duorarum) on the Tortugas Shelf of Florida, August 1962October 1964. Fish Bull (Seattle) 67:165-181

Penn JW (1975) The influence of tidal cycles on the distribution pathway of Penaeus latisulcatus Kishinouye in Shark Bay, Western Australia. J Mar Freshw Res 26: 93-102

Power JH (1997) Time and tide wait for no animals: seasonal and regional opportunities for tidal stream transport and retention. Estuaries 20:312-318

Queiroga H, Costlow JD, Moreira MH (1994) Larval abundance patterns of Carcinus maenas (Decapoda, Brachyura) in Canal de Mira (Ria de Aveiro, Portugal). Mar Ecol Prog Ser 111:63-72

Rehrer RA, Jones AC, Roessler MA (1967) Bottom water drift on the Tortugas Grounds. Bull Mar Sci 17:562-575

Rothlisberg PC, Church JA, Forbes AMG (1983) Modelling advection of vertically migrating shrimp larvae. J Mar Res 41:511-538

Rothlisberg PC, Church JA, Fandry C (1995) A mechanism for near-shore density and estuarine recruitment of postlarval Penaeus plebejus Hess (Decapoda, Penaeidae). Estuar Coast Shelf Sci 40:115-138

Shanks AL (1995) Mechanisms of cross-shelf dispersal of larval invertebrates and fish. In: McEdward LR (ed) Eco-

Editorial responsibility: Otto Kinne (Editor-in-Chief), Oldendorf/Luhe, Germany logy of marine invertebrate larvae. CRC Press, Boca Raton, FL, p 323-367

Shay LK, Lee TN, Williams EJ, Graber HC, Rooth CGH (1998) Effects of low-frequency current variability on nearinertial submesoscale vortices. J Geophys Res C 103: 18691-18 714

Smith NP (1994) Long-term Gulf-to-Atlantic transport through tidal channels in the Florida Keys. Bull Mar Sci 54: 602-609

Smith NP (2000) Transport across the western boundary of Florida Bay. Bull Mar Sci 66:291-304

Smith NP, Stoner AW (1993) Computer simulation of larval transport through tidal channels: role of vertical migration. Estuar Coast Shelf Sci 37:43-58

Tabb DC, Dubrow DL, Jones AE (1962) Studies on the biology of pink shrimp Penaeus duorarum Burkenroad, in Everglades National Park, Florida. Fla Bd Conserv Mar Res Lab Tech Ser 37:1-32

Temple R, Fischer CC (1965) Vertical distribution of the planktonic stages of penaeid shrimp. Publ Inst Mar Sci Univ Tex 10:59-67

Yeung C, Jones DL, Criales MM, Jackson TL, Richards WJ (2001) Influence of coastal eddies and counter-currents on the influx of spiny lobster, Panulirus argus, postlarvae into Florida Bay: influence of eddy transport. Mar Freshw Res 52:1217-1232

Submitted: January 27, 2004; Accepted: July 15, 2004 Proofs received from author(s): January 17, 2005 